\title{
The Foundation for Environmental Conservation: Origins, Objectives, and Needs
}

The Foundation (FEC), which had started operating unofficially some years earlier, was finally established legally in 1975 at Grand-Saconnex, Geneva, Switzerland, as non-profit and tax-exempt by authority of the Council of State of the Republic and Canton of Geneva and perpetually under Swiss Federal Government surveillance by the Department of the Interior, Berne. Its viewpoint and emphasis are holistically global and its activities as widely international as possible. Its headquarters and Secretariat are at 7 Chemin Taverney, 1218 Grand-Saconnex, Geneva, Switzerland (telephones [022] 7982383 \& 798 2384).

FOUNDERS AND GOVERNING BOARD

The Founders were the International Union for Conservation of Nature and Natural Resources (IUCN), the World Wildlife Fund (now renamed World Wide Fund for Nature) International (WWF), both currently situated at Gland, Switzerland, and Professor Dr Nicholas Polunin, of the above address. The Governing Board of the Foundation consists of the last-named for life and a representative each of IUCN and WWF, with powers to co-opt a very limited number of other members for periods of three years at a time (renewable for similar periods).

\section{OBJECTIVES (UPDATED)}

A. To undertake, in cooperation with appropriate individuals, organizations, and other groups, all possible activities to further the ends indicated in its title, and specifically:

B. To own and promote pertinent publications, in particular the international Journal Environmental Conservation, and to derive therefrom revenues to be used especially towards coverage of publication costs - in mind are certain other journals, possible supplements to the present one, and, ultimately, much-needed works of reference. The Foundation-sponsored, open-ended series of Environmental Monographs \& Symposia started publication in 1981, and a complementary series of shorter 'readers', entitled Cambridge Studies in Environmental Policy, will soon be coming into production: the latter at least will be paying a royalty to the Foundation.

C. To foster pertinent conferences, in particular the International Conferences on Environmental Future (ICEFs), and to sponsor the Baer-Huxley Memorial Lectures;

D. To organize specialist 'Workshops' etc. to deliberate and pronounce freely on urgent aspects of environmental despoliation or other causes for grave concern, e.g. the widespread die-back of trees and more general devegetation;

E. To encourage, and where possible promote, studies on environmental change, including ecobiome and ecosystem development and maintenance;

F. To institute through appropriate auspices, and thereafter continue to sponsor and promote, the World Campaign for The Biosphere, 1982-, whose functions are henceforth to be fostered primarily by the World Council For The Biosphere (see 6 below) and the affiliated International Society For Environmental Education; and

G. to accept and administer (under Swiss Federal surveillance by the Department of the Interior, Berne, and the authority of the Council of State of the Republic and Canton of Geneva, tax-exempt funds for the above purposes, including the creation and bestowal of suitable awards for environmental achievement and allied enterprise.

\section{Environmental Conservation}

The Foundation having reassumed financial responsibility for the printing and production of the Foundation's Journal, and help from the United Nations Environment Programme and other sources having covered incidental needs of the Journal through 1988, funds are required continuingly for its support in such ways as subventions for extra pages published beyond the standard 88 of text per issue and to pay for illustrations, proof corrections, 'free' offprints, and other incidental expenses which hitherto were largely contributed with his services by the President in his capacity as Editor but which mounting costs and personal taxes are making it increasingly difficult for him to support unaided. In addition, funds are desirable (1) to cover more editorial and incidental expenses, and (2) to increase the value of a prize or prizes for the best paper or papers published each year in Environmental Conservation or otherwise through the Foundation.

The cumulative 'Index of Titles and Authors in Environmental Conservation, 1974-86', comprising 159 pages in the format of the Journal, is now published and available from the Foundation's Secretariat (address below) at the price of US $\$ 30$ or Sw.Frs 45 (postage included). It is being followed by a supplement covering the years 1987 and 1988 which is being sent free to all purchasers of the original Index while stocks last, and thereafter by 5 -yearly supplements.

\section{Office and Allied Expenses}

With ever-mounting costs and taxes (though the Foundation itself is non-profit and tax-exempt), and problems inter alia of currency exchange, it is becoming increasingly difficult to maintain the Secretariat privately, despite assistance from the Journal's Publisher and intermittent help from United Nations and other sources. Consequently funds are needed to help defray essential office etc. expenses -including those of two telephones and heavy postage, subscriptions, purchases of reference works and other equipment, extra pages of the Journal, useful reprinting and entertaining, and necessary travel when sanctioned by the Board. In addition, some financing is now desired for payment of further casual assistance, attendance at conferences and meetings, and reimbursement of services etc. paid for in maintaining and supplying the Secretariat.

\section{International Conferences on Environmental Future}

Whereas the President's family hopes to continue to refrain from reclaiming the amount still owing to him personally in respect particularly of the 2nd ICEF (actually from the proceeds of the ad hoc sale of his Arctic library to the Government of Canada) and the 3rd ICEF etc. (especially from the International Sasakawa Environment Prize, 1987) as indicated in the yearly accounts, substantial sums will be needed to carry out any further ICEFs, though it is expected that the bulk of necessary financing will in general be contributed by or through the suitable host countries. The first ICEF in 1971 cost approximately $\$ 44,000$ (apart from relieving gifts and the generosity of the host Government of Finland) and the 2nd ICEF c. $\$ 65,000$ (including preparation and publication of the Proceedings in adequate detail, but apart from the help of the host Government of Iceland and various Icelandic services). The much smaller 3rd cost $c . £ 20,000$.

The 3rd ICEF took place in September 1987 in Edinburgh, Scotland. It was limited to 75 invited participants and lasted the equivalent of only two days, being organized as a lead-in to a 4th ICEF, which will be much larger and 
longer and held, in the spring of 1990 in Budapest (by invitation of the Hungarian Academy of Sciences) on the theme of Surviving With The Biosphere; it is likely to cost about twice as much as the 2 nd ICEF (after the input of the host Country) with the need nowadays to help with the expenses of an increasing proportion of participants, and so the 'ideal' budget has been divided into six units of $\$ 20,000$ each, which are accordingly being sought - for accommodation, fares, administration, publicity and publication, honoraria etc., and incidentals. These last include the Baer-Huxley Memorial Lecture and propitious workshops.

\section{Other Journals and Series of Books}

(a) Means are desired to encourage and help further needed journals through sponsorships, memberships, or grants, an example being Environmental Awareness, the organ of the International (formerly Indian) Society of Naturalists (INSONA), of which the President and his Wife are Patrons. Other instances include The Biosphere and the Bulletin of the Asian Society for Environmental Protection, of which the President is a Life Member.

(b) Environmental Monographs \& Symposia: Means are desired to support special cases with a leading international Publisher, and to help (c) the complementary Cambridge Studies in Environmental Policy series (likewise sponsored by the Foundation), consisting of highly authoritative 'readers' for environmental policymakers, politicians, and the enlightened public.

\section{World Education Concerning The Biosphere}

With the object of promoting world-wide knowledge of The Biosphere and appreciation of how humans are an integral part of it and utterly dependent on it, and yet are threatening it with their ever-increasing numbers and pressures on its finite resources, there were proposed in Environmental Conservation successively an 'International Year of the Biosphere' that was soon extended to 'The World Decade of The Biosphere, 1982-92' but then redesignated and subsequently declared as 'The World Campaign for The Biosphere, 1982-', which the Foundation initiated and continues to sponsor but which, as of early October 1983, was taken over by the joint World Council For The Biosphere-International Society for Environmental Education - the former of which was founded primarily to foster the World Campaign for The Biosphere, while the latter became most closely associated with the North American Association for Environmental Education (NAEE), of which the President is a Life Member. The former joint body was commonly referred to by its acronym of WCB-ISEE and had a Joint Coordinating Committee (JCC); but after three years of trial this last was abandoned 'in the interests of simplicity for direct action' and WCB and ISEE effectively separated, though with the advising of ISEE a major responsibility of WCB, which has now come more fully under the aegis of the Foundation, as was advised by the Foundation's governmental supervisors. WCB has latterly been strengthened with the election of a full complement of 21 Councillors, the agreed adoption of a binding Constitution, and the appointment of Sir John Burnett as Executive Secretary.

\section{The World Council For The Biosphere}

The origins of this body, henceforth to function autonomously but as an important project of the Foundation, are explained in the last paragraph above, its main purpose being 'to safeguard the continuing integrity of The Biosphere by serving as a select international forum for the analysis and appraisal of existing and foreseeable relationships between human population and economic develop- ment on one hand and, on the other, the totality of living and life-support systems of our planet which collectively constitute The Biosphere.' For subsidization of the general running and meetings of WCB, reimbursement of costs especially of its Executive Secretary, travel by its appointed officers and sanctioned maximum of 17 other Councillors or their nominees, and satisfaction of various concomitant needs, an endowment of one million US dollars or more Swiss francs is needed urgently and being sought, as agreed by the Governing Board of the Foundation and approved in principle by both of the governmental supervisors.

\section{Research and Writing Projects}

(a) Various worthy research projects have been encouraged with due publication of their results, but a budgetary item to help future ones financially would be welcomed. As a specific item it is thought that a project on Nature in Concrete Jungles could be promoted with little special financing, at least in its early stages.

(b) Among writing and editing projects, in addition to the President's recent Ecosystem Theory and Application in the Environmental Monographs \& Symposia series, may be cited the need of a new edition of his Introduction to Plant Geography and Some Related Sciences which, though published in 1960 and now badly outdated, is still being widely used and even translated (currently into Indonesian). The new edition should include additional sections on pollution effects and ecology, plant conservation, introductions and their effects, competition, continental drift, and the role of plants in environmental conservation-for all of which, and widespread updating, specialist collaboration will be needed.

\section{Other Desiderata}

(a) Feasibility study of a proposed top-level World Academy of Environmentalists (now that the educational etc. aspects are being furthered especially by the international bodies mentioned in No. 5 above and by more and more national and regional ones).

(b) Compilation of a planned World Who's Who in Environment \& Conservation: Leading Specialists, Administrators, and Benefactors, which should be related to (a) and an organizational-institutional counterpart that is now being compiled in California.

(c) Practical proposal of a World Wilderness Alliance.

(d) Investigation of the practicability of establishing an international environmental centre and/or 'conservation campus'-such as was discussed at the 12th AGM of the Foundation and for which an ad hoc feasibility study also seems urgent.

(e) Endowment of the Baer-Huxley Memorial Lectures on topics of contemporary environmental concern, normally given in connection with International Conferences on Environmental Future (see 3 above).

(f) Endowment of a prize or prizes for the best paper or papers published each year in Environmental Conservation or a book sponsored by the Foundation, and ultimately of a major award or awards for environmental achievement and enterprise. Based on the findings of a small secret Awards Committee, the first 'best paper' prizes were awarded early in 1987 and had to be modest as coming substantially from the Foundation's savings from only giving out free offprints when requested on the green ordering forms accompanying proofs. Four prizes were awarded in 1988.

(g) Encouragement of a Canadian initiative for 'The Arctic as a Regional Sea'.

(h) Funds to convene working groups of leading specialists to pronounce quite freely on major environmental threats and advise WCB (see 5 and 6 above) concomitantly. 
An endowment of US $\$ 8$ millions or Sw.Frs 12 millions would suffice for this and meanwhile satisfy other of the above needs from income.

(i) Sponsorship without financial commitment of appropriate conferences such as the projected series of International Conferences on Waste Minimization and Clean Technology.

Further projects are under consideration, including urgent research proposals, a major World Heritage Series of volumes, establishment of a biennial award for demonstrated environmental concern and concomitant action by a multinational corporation, and fostering the establishment of associated foundations etc. in other parts of the world.* With the demise of the Pahlavi Prize, the modest value by modern standards of its successor the International Sasakawa Environment Prize, and the opening of the Tyler Prize to wider concerns, a major award for environmental leadership is an urgent need-if possible on a par with the Nobel Peace Prize (for which, incidentally, the nomination of leading environmentalists seems particularly desirable).

\section{OpERATION AND NEEDS}

With the running costs already largely accounted for, and in the absence of any institutional overheads and taxes other than those that continue to be paid privately, the Foundation constitutes what has been called a uniquely economical vehicle for support of the environmental/conservational movement-whether generally or through specific projects which can be put in train as soon as or soon after funds become available. Contributions are warmly welcomed and individually acknowledged, and can be received in any negotiable currency by cheque made out to the Foundation for Environmental Conservation, c/o $\mathrm{Mr}$ Heinz Christen, Pictet \& Cie Banquiers, 29 Boulevard Georges-Favon, 1204 Geneva, Switzerland, or sent to the Foundation's address ending this notice. [Plans for recognizing special services or substantial donations to the Foundation by the award of an engraved certificate designed by a renowned draughtsman have been shelved with the death of the draughtsman and in view of the urgent need of all available funds for more pressing purposes, though donors are requested to identify themselves clearly unless anonymity is desired.]

\author{
Nicholas Polunin, President \\ The Foundation for Environmental Conservation \\ (updated version following its 14th Annual General \\ Meeting, held on 28 February 1989). \\ Address: 7 Chemin Taverney, \\ 1218 Grand-Saconnex \\ Geneva, Switzerland.
}

* These include the International Vernadsky Foundation. established in 1988 and centred on the USSR. of which the President is one of the 10 Founders, and an International Centre for Biosphere Studies, which has recently been recommended. inter alia at our urging, to be located in the Institute of Soil Science and Photosynthesis in Pushchino. USSR. They also include the (Indian) National Environmental Conservation Association, of which the President is a life Member and a Member of the Advisory Board. and the collaborating International Society of Naturalists (INSONA), of which the President is an elected Fellow and Patron.

\section{The Need for a World Conservation Archive}

In a few years' time, through the courtesy of the Swiss authorities. IUCN hopes to move to a new headquarters building. The design of an appropriate building is now being considered, and this note proposes that, within it, a World Conservation Archive should be established.

\section{Why a Conservation Archive is Important}

When the history of the late 20th century comes to be written, it seems very probable that one of the features which will strike the historian most forcibly is the mounting recognition of human impact on the natural world, and the need to conserve and manage its renewable resources if humanity is to have a future. The growth of conservation activities from the 1940s onwards, led by pioneers of long experience and mounting concern and marked in 1948 by the creation of IUPN (the International Union for Protection of Nature), later to become IUCN, will stand out as one of the landmarks on this historical pathway.

Historians will want to analyse just what happened, why, and how the key actors in the drama behaved. They will not be satisfied with the generalizations in the published sources, and will want to go back to original records of meetings, correspondence, diaries, and the like. This can only be done effectively if such unique material is safeguarded for future scholarly scrutiny, and a specialist conservation archive is surely the answer to such a need.

\section{Location of an Archive}

The right place for such an archive is obviously in the new headquarters of IUCN - the World Conservation Union. IUCN itself has already a wealth of such documents pertinent to the history of this period, and there are many people still alive who played a central part in the early years of establishment of IUPN and IUCN and who would willingly deposit their material with the new archive if it was established and supervised under proper, modern conditions, with the curation of the material thereby guaranteed. Steps need to be taken urgently to reassure such individuals that this will be done.

There are a number of specialized archives in other fields. They are much sought after by scholars. For example, the history of research into the exploration of the polar regions is particularly based on studies of such archives as that at the Scott Polar Research Institute in Cambridge, England, UK, where proper air-conditioned facilities permit the safe keeping of unique manuscripts from the age of Antarctic exploration around the turn of the century and the earlier periods of Arctic discovery over 150 years ago. When once a good archive is established, it tends to attract material and progressively increase its value to scholars.

\section{The Design of an Archive}

It is proposed that special, air-conditioned facilities be designed in the new IUCN headquarters, on the advice of a professional curator of such material. The room or rooms concerned would need to be located alongside, and curated in association with, the IUCN library. This in itself needs to be planned and endowed as a unique collection of conservation literature, much of it donated by well-wishers to IUCN over the years. A World Conservation Library alongside a World Conservation Archive would be of immense value to visiting scholars, who would also benefit from day-to-day contact with the staff of the World Conservation Union. 